\title{
Juridical Review Of The Judge's Decision In The Credit Agreement Decision (Case Study Of Decision Case Number 40 / Pdt.G / 2019 / Pn.Mdn)
}

\author{
Said Rizal $^{1}$, Veronika ${ }^{2}$, Yosua Christian Harefa ${ }^{3}$, Cicilia Abigael Valmaru Sitinjak ${ }^{4}$, \\ Gabryel Radella Septani Purba ${ }^{5}$ \\ \{saidrizal@unrpimdn.ac.id\} \\ Universitas Prima Indonesia ${ }^{12345}$
}

\begin{abstract}
As for the definition of credit listed in Article 1 Number 11 UU No10/1998 concerning Banking: "That credit is the provision of money or bills that can be equated with it, based on the agreement and loan agreement between the bank and other parties that oblige the borrower to pay off his debt after a certain period of time with interest". How is the juridical analysis of the judge's consideration of rejecting the lawsuit in the verdict case 40 / Pdt.G / 2019/2019 / PN. The method of data collection used in the writing of this thesis is through document study and library research method. Data analysis uses qualitative methods that produce descriptive analytical data. Based on the consideration of the Panel of Judges against the lawsuit filed by the Plaintiff with the legal facts revealed in the trial, the Panel of Judges who adjudicate this case states that the lawsuit should be a "resistance" to the process of selling the auction of aset of plaintiffs due to bad credit conducted by Defendant I with the help of Defendant II.
\end{abstract}

Keywords: Credit, Default lawsuit

\section{Introduction}

Basically, humans are social creatures and cannot fulfil their own life. A person cannot live comfortably if his needs are not met. To meet the economic needs of the community, the existence of a financial institution or a banking company can help the community's unmet needs. Banks can be defined as financial institutions whose business activities collect funds from the public and channel these funds back to the public and provide other services such as credit. The meaning of credit as stated in Article 1 Number 11 of Law Number 10 of 1998 concerning Banking: "Whereas credit is the provision of money or an equivalent claim, based on a loan and loan agreement between the bank and another party which requires the borrower to pay off its debt after a certain period of time with interest."

In the Banking Law that provides credit, there must be a credit agreement. Agreement is: "An action with which one or more parties bind themselves to one or more people". Credit agreements are provisions that have legal certainty and apply as law for the parties related to the agreement. From the agreement, there is a legal relationship between the two parties that made it, which is called the engagement. An engagement is a relationship between two people or two parties in the field of property law on the basis of which one party has the right to demand something from the other party, and from the other party is obliged to fulfil said demand. Basically, in an engagement there are two parties, the first party is the party entitled 
to claim something, which is called the creditor, while the second party is the party hereinafter referred to as the debtor, the claim in the law is referred to as "achievement".

In implementing the Bank's credit agreement, it is possible that one of the parties will default or neglect the obligations stated and mutually agreed upon in the credit agreement. In default, there are three forms or criteria, namely: "The authorized party does not perform at all: The authorized party is late in carrying out its obligations: and Carrying out obligations but not properly or as well as possible". In Case Decision Number 40 / Pdt.G / 2019 / PNMdn between Hidayat Kusuma and 1. PT. BANK OCBCNISPTbk (Director) and 2. Ministry Of Finance Of The Republic Of Indonesia.

The case of default committed by Mr. Hidayat Kusuma against PT. BANK OCBCNISPTbk,). To deal with disputes between debtors and creditors, an independent institution, namely a court, is needed. This court as one of the judicial powers has a very important role in deciding the dispute or dispute. Based on the description above, the authors are interested in being able to carry out scientific research with the title "Juridical Review Of The Judgment's Decision In Credit Agreement Wanprestation Claims (Case Study On Case Decision No. 40 / Pdt.G / 2019 / PN.Mdn)"

The problems in this research are as follows:

1. What is the juridical analysis of the judges' considerations in the verdict of the case 40 / Pdt.G / 2019/2019 / PN?

2. What was the reason for the panel of judges rejecting the default suit In the case verdict 40 / Pdt.G / 2019 / PN.Mdn?

\section{Results and Discussion}

\subsection{Default in the Credit Agreement according to the Legislation in Indonesia}

In Article 1 number 11 of Law Number 10 of 1998 concerning amendments to Law Number 7 of 1992 concerning Banking, the definition of Credit is explained: " Credit is any form of provision of money or claims equivalent to it, this is based on approval or a loanborrowing agreement between the bank and another party which requires the borrower to pay off its debt after a certain period of time with interest.

The agreement in a Credit Agreement must be made in writing. This is based on the provisions contained in the elucidation of Article 8 of Law Number 7 of 1992 concerning Banking, which obliges banks as lenders to make written agreements. The banking agreement obligations that require a written agreement have been stipulated in the main banking regulations by Bank Indonesia as referred to in Article 8 paragraph (2) of the Banking Law. In Article 10 of Law Number 4 of 1996 it is stated that the agreement that creates a debtreceivable relationship in which the guarantee for repayment can be made in 2 (two) forms, namely in the form of an underhand deed or an authentic deed depending on the legal provisions governing the material of the agreement between the two the party. The credit agreement is intended as evidence and provides limits on and the obligations of each party.

\subsection{Analysis of Medan District Court Decision Number 40 / PDT.G / 2019 / PN.MDN Civil Procedure Code}

Formal law which functions to defend and enforce material civil law in the event of a violation. Civil Procedure Law (BurgerlijkeRechtsvordering), namely formal legal regulations that govern how to ensure compliance with material civil law through an intermediary judge. 


\section{a. Lawsuit}

The first will be reviewed from the lawsuit. HidayatKesuma as the Plaintiff is a debtor from PT. Bank OCBCNISPTbk (Director) as Defendant I. However, in this case, the Plaintiff also included the Ministry of Finance of the Republic of Indonesia as Defendant II. Whereas the Plaintiff received a Multi-Use Credit facility of Rp. 300,000.00.00 from PT. Bank OCBCNISPTbk with collateral in the form of a plot of land and a house and its derivatives. This credit was used for the Plaintiff's business capital, namely the provision of medical equipment. To pay off this credit, the Plaintiff has been in instalments for approximately 3 years, starting from February 10, 2015 to February 10, 2025, with the amount of monthly instalments of Rp.4,500,000.00. According to Defendant I, the remaining debt of the Plaintiff is currently totaling Rp296,974,009.00 including current interest costs, penalties and principal payment duties.

However, the Plaintiff's medical equipment supply business suffered losses, causing the Plaintiff to only be able to pay the last installment on October 1, 2018 to Defendant I. carry out the auction of the Plaintiff's credit collateral. The Plaintiff objected to this, also objected to the remaining debt stated by Defendant I amounting to Rp296,974,009.00 because the Plaintiff had been in installments for approximately 3 years.

Therefore, the Plaintiff hopes to receive relief from the total debt of Defendant I, amounting to Rp180.00,000.00. In their lawsuit, the Plaintiff also requested that Defendant I submit collateral in the form of land / house certificates, namely SHM No. 7382 and its derivatives in the name of HidayatKesuma located in North Sumatra Province, Medan City, Kec. Medan Selayang, Village / Kel.Tanjung Sari, covering an area of $\pm 84 \mathrm{M}^{2}$, or locally known as Jl. Grand Nusa Setia Budi Complex C7 Ring I, Road Pasar 2 Kel. Tanjung Sari, Kec. Medan Selayang, Medan City to the Plaintiff.

According to the author, the Plaintiff's lawsuit can be said to be vague or Obscure Libel because it does not clearly state whether the Defendants' actions are illegal or in default, because the Plaintiff only stated that Defendant, I did not understand the good faith of the Plaintiff to repay the credit, but so on, the Plaintiff stated that the Plaintiff objected to the remaining installments stated by Defendant I because he felt that the debt was not reduced, amounting to Rp296,974,009.00. However, from a legal perspective, this is very possible because so far, the Plaintiff has just paid interest on the credit.

Based on Article 1 number 11 of Act Number 10 of 1992 concerning Banking, credit is defined as the provision of money or an equivalent claim, based on a loan-borrowing agreement between the bank and another party which requires the borrower to repay the debt after a period of time. certain by giving flowers. Based on this definition, a credit agreement can be interpreted as a lending-borrowing agreement between a bank as a creditor and another party as a debtor, which requires the debtor to pay off his debt after a certain period of time by giving interest.

The definition of a credit agreement has not been well formulated in the Banking Law. Therefore, there are several opinions to understand the meaning of a credit agreement. Subekti stated that in whatever form the provision of credit was made, in essence what happened was a loan and loan agreement as regulated by the Civil Code Article 1754 to Article 1769. The same opinion was expressed by Marhainis Abdul Hay who stated that the credit agreement was identical. with a borrowing agreement and controlled by the provisions of Chapter XIII of Book III of the Civil Code. Gatot Supramono also stated that the credit agreement is a loan and replace agreement, but also a special agreement, because in it there is a specificity in 
which the creditor as the bank and the object of the agreement in the form of money (generally regulated by the Civil Code and specifically regulated by the Banking Law).

From all of the above opinions, it is very clear that the credit agreement is a "law" that binds both parties, where if there is either a debtor or creditor who does not carry out what has been stated in the law, then the sanctions that has been agreed upon can be implemented. According to the author, in this case, Defendant I continued the Plaintiff's credit problem to the Defendant to auction off the Plaintiff's credit collateral, in the form of a plot of land and a house and its derivatives which had previously been used as collateral by the Plaintiff.

\section{b. Defendant's Exception I}

In its exception, Defendant I stated that the Plaintiff mistakenly took legal action against the lawsuit, because legally the Plaintiff should have filed in the form of "resistance" to the Plaintiff's asset auction sale process due to bad credit carried out by Defendant I with the assistance of Defendant II. When the auction process has been carried out and the auction process has been completed, then the mechanism for legal action will be opened through the filing of a lawsuit by the Plaintiff. Apart from that, the Plaintiff in the arguments for a quo lawsuit, basically has explicitly and clearly acknowledged the Plaintiff as a customer of Defendant I who had received a credit facility. However, the Plaintiff did not carry out its obligations as agreed, resulting in the Plaintiff being stopped from making payments / bad credit. So, there is a very legal reason for the Panel of Judges who tried the a quo case to declare the Plaintiff's claim unacceptable (NietOnvankelijkVerklaard).

In the author's view, in accordance with the credit agreement between the Plaintiff and Defendant I, Defendant I did not violate the clauses in the agreement. On the other hand, the Plaintiff was in default by not continuing the payment of installments, so that the objects that had been guaranteed by the Plaintiff were auctioned off by Defendant I. In the credit agreement, the guarantee is a liability that can be valued in money, namely in the form of certain items that the debtor has handed over to the creditor as a result of a debt agreement or other agreement. Certain items submitted by the debtor to the creditor are intended as coverage for loans or credit facilities provided by the creditor to the debtor until the debtor repays the loan, if the debtor is in default, certain items will be valued in money. Furthermore, it will be used to pay off all or part of the debtor's loan or debt to his creditors. In other words, the guarantee serves as a means to guarantee the fulfillment of the debtor's loan or debt in case of default before the maturity date of the loan or the debt ends.

\section{c. Defendant's Exception II}

Defendant II stated that it had no relationship at all with the settlement of the credit facility obtained by the Plaintiff from PT Bank OCBCNISPTbk, Asia Branch, Medan, incasu, Defendant I. Due to the things that have been conveyed in their exception, Defendant I and Defendant II requested that the Panel of Judges reject all or at least state that the Plaintiff's claim is unacceptable and that the Plaintiffs pay all costs incurred in the case.

\section{d. Decision}

Based on the Judge's consideration of the lawsuit filed by the Plaintiff and with the legal facts revealed in the trial, the Panel of Judges adjudicating this case stated that the lawsuit should be in the form of resistance to the auction sale process over the auction sale process of Plaintiff's assets due to bad credit committed by Defendant I. With the assistance of Defendant II, when the auction process has been carried out and completed, then the mechanism for legal action will be opened through the filing of a lawsuit by the Plaintiff. Therefore, the Plaintiff 
mistakenly submitted a quo legal remedy and the lawsuit was declared obscure, obscure (obscure libels), because the Plaintiff in formulating the arguments for his lawsuit was not clear regarding the qualifications of the violation of the law committed by Defendant I, whether the qualifications of the law (onrechtmatigedaad) or in the qualification of broken promises / defaults as explained in the exceptions of Defendant I and Defendant II.

Apart from that, Defendant I did not have anything to do wrong or act that could harm the Plaintiff, including a request for the Plaintiff to hand over Rp180,000,000 (one hundred and eighty million rupiahs) and sentence Defendant I to hand over the collateral. Therefore, the Panel of Judges is of the opinion that the Plaintiff's claim is not based on law or clear legal qualifications so that the exceptions of Defendant I and Defendant II have grounds to be declared acceptable. Thus, it can be concluded that Defendant I's action in passing on the bad credit to Defendant II to carry out an auction of the objects that have been guaranteed by the Plaintiff is a legal act in the eyes of law, because Security Rights are collateral rights imposed on land rights as referred to in UU no. 5 of 1960 concerning Basic Agrarian Principles and Law No. 4 of 1996 concerning Mortgage Rights, for the settlement of certain debts that give priority to certain creditors over other creditors.

In addition, according to the author's view, the Plaintiff's objection regarding the debt which he feels has not reduced even though it has been in installments for approximately 3 years has no good reason, because according to the Banking Law the loan-borrowing relationship between the Plaintiff as a Debtor and Defendant I as a Credit given is accompanied by mutually agreed interest, so it is possible if all this time the only interest has been paid in installments by the Plaintiff considering the grace period for repayment of the credit is in 2025 .

\section{Conclusion}

The obscurity of the Plaintiff's lawsuit or obscuur libel was due to not clearly stating whether the Defendants' actions were illegal or in default, because the Plaintiff only stated that Defendant, I did not understand the good faith of the Plaintiffs to pay off the credit. In the Defendant's exception, the Defendant stated that the Plaintiff made a mistake in taking legal action for the lawsuit, because the Plaintiff should have legally filed it in the form of "resistance" to the Plaintiff's asset auction sale process due to bad credit carried out by Defendant I withthe assistance of Defendant II.

Based on the consideration of the Panel of Judges against the lawsuit filed by the Plaintiff with the legal facts revealed at the trial, the Panel of Judges who tried this case stated that the lawsuit should be in the form of "resistance" to the Plaintiff's asset auction sale process due to bad credit carried out by Defendant I with the assistance of Defendant II, if the auction process has been carried out and completed, then the mechanism for legal action will be opened through the attempt to file a lawsuit by the Plaintiff.

\section{Suggestion}

According to the authors, the Plaintiff must understand that the lawsuit should be in the form of resistance to the Plaintiff's asset sale process due to bad credit carried out by Defendant I with the assistance of Defendant II, if the auction process has been carried out and the auction process has been completed, then the mechanism of legal action will be opened through efforts to file a lawsuit by the Plaintiff. In law, the lack of clarity in a lawsuit is 
something that often happens, because so far the Plaintiff has just paid interest on the credit, however the Plaintiff's caution in making a lawsuit must also be more careful to avoid the cancellation of a lawsuit.

\section{References}

[1] Undang-UndangNomor 10 Tahun 1998 tentangPerbankan

[2] Hermansyah, HukumPerbankanNasional Indonesia, Kencana, Jakarta,2006.

[3] Salim HS, EriliesSeptianaNurbani, PerbandinganHukumPerdata, PT Raja GrafindoPersada, Jakarta.

[4] Kasmir, Bank danLembagaKeuanganLainnya, RajawaliPers, Jakarta,2004.

[5] R. Setiawan, Pokok-pokokHukumPerikatan, BinaCipta, Bandung, 2007.[6] WirjonoProjodikoro, Asas-asasHukumPerjanjian, PT. Bale, Bandung, 985.

[6] Bahder Johan Nasution, MetodePenelitianIlmuHukum, MandarMaju,Bandung.

[7] RiantoAdi, MetodePenelitianSosialdanHukum, Granit, Jakarta, 2004.

[8] SoerjonoSoekanto, PengantarPenelitianHukum, UI Press, Jakarta.

[9] Mardalis, MetodePenelitianSuatuPendekatan Proposal, BumiAskara,Jakarta, 2004.

[10] H.R. DaengNaja. 2005. HukumKreditdan Bank Garansi, The Bankers HandBook.Bandung : PT Citra AdityaBakti.

[11] SudiknoMertokusumo, 1993, HukumAcaraPerdata Indonesia, Liberty, Yogyakarta.

[12] Subekti, Jaminan-JaminanUntukPemberianKreditMenurutHukum Indonesia, Alumni, Bandung, 1982.

[13] Marhais Abdul Hay, HukumPerbankan di Indonesia, PradnyaParamita,Bandung, 1975.

[14] RachmadiUsman, HukumJaminanKeperdataan, SinarGrafika, Jakarta,2008 